Dorota Grego-Planer

\title{
POTENCJAŁ INNOWACYJNY MAŁYCH I ŚREDNICH PRZEDSIĘBIORSTW MAKROREGIONU GRUDZIĄDZKIEGO
}

Z a rys treś c i. W artykule zaprezentowano fragment wyników badań empirycznych na temat potencjału innowacyjnego małych i średnich przedsiębiorstw w województwie kujawsko-pomorskim. Jednym z celów badania była identyfikacja kluczowych uwarunkowań zewnętrznych wpływających na potencjał innowacyjny małych i średnich firm, jak również identyfikacja kluczowych składników tego potencjału. Opracowanie przedstawia wyniki badań obejmujące przedsiębiorstwa makroregionu grudziądzkiego.

Słow a kluczowe: potencjał innowacyjny, małe i średnie przedsiębiorstwa.

\section{WSTEP}

W dobie tak szybko postępującej globalizacji coraz większego znaczenia nabierają wszelkiego rodzaju innowacje. To one wielokrotnie stają się dla przedsiębiorstw ogromną szansą na walkę z konkurencją i jednym z podstawowych czynników ich rozwoju. Samo wdrożenie innowacji nie jest jednak procesem łatwym. Aby przedsiębiorstwo mogło skutecznie prowadzić działalność innowacyjną, musi dysponować szeroko pojętym potencjałem innowacyjnym. Celem artykułu jest zaprezentowanie fragmentu wyników badań empirycznych, wskazujących między innymi na kluczowe składniki potencjału innowacyjnego, jak również na uwarunkowania zewnętrzne jego budowy w małych i średnich przedsiębiorstwach makroregionu grudziądzkiego. 


\section{POTENCJAŁ INNOWACYJNY W ŚWIETLE TEORII}

W literaturze przedmiotu można spotkać wiele definicji potencjału innowacyjnego przedsiębiorstw. Począwszy od tych, które definiują go bardzo wąsko, kończąc na ujęciach bardzo szerokich. W artykule zaprezentowano kilka wybranych ujęć potencjału innowacyjnego.

Jedno z nich proponuje K. Poznańska, zdaniem której potencjał innowacyjny przedsiębiorstwa to jego zdolność do efektywnego wprowadzania innowacji, czyli nowych produktów, nowych technologii, metod organizacyjnych i innowacji marketingowych otoczenia. Tak określany potencjał kształtowany jest przez cztery kluczowe elementy (Poznańska, 1998, s. 40):

1) potencjał finansowy,

2) potencjał ludzki,

3) potencjał rzeczowy,

4) wiedzę.

Potencjał finansowy to głównie własne środki finansowe oraz środki oferowane przez różnego rodzaju instytucje finansowe i pozafinansowe, działające $\mathrm{w}$ regionie funkcjonowania przedsiębiorstwa. Potencjał ludzki natomiast, to przede wszystkim liczba zatrudnionych pracowników i ich struktura oraz posiadane przez nich kwalifikacje i umiejętności. Do potencjału rzeczowego należy zaliczyć strukturę aparatu produkcyjnego wraz z jego elastycznością, czyli możliwością szybkiego dostosowania produkcji do zmieniających się potrzeb na rynku. Należy również tu uwzględnić wiek i poziom mechanizacji oraz automatyzacji parku maszynowego. Ostatnim z elementów potencjału innowacyjnego jest wiedza. Tu należy skupić się przede wszystkim na wiedzy technicznej oraz na płynących z rynku informacji.

Poznańska podkreśla ogromną rolę otoczenia, które w bardzo istotny sposób wpływa na elementy składowe potencjału innowacyjnego. Oddziaływanie tego otoczenia pozwala na wyróżnienie zewnętrznego i wewnętrznego potencjału innowacyjnego przedsiębiorstwa (Poznańska, 1998, s. 41).

Przez wewnętrzny potencjał innowacyjny Poznańska rozumie zasoby i umiejętności, jakimi dysponuje przedsiębiorstwo, które mogą zostać wykorzystane w bieżącej działalności innowacyjnej. Zadaniem przedsiębiorstwa w tym obszarze jest gromadzenia zasobów rzeczowych, zbieranie informacji dotyczących najnowszych trendów rozwoju technologicznego, wartościowanie informacji oraz podejmowanie decyzji w poszczególnych obszarach działalności przedsiębiorstwa, takich jak finanse, marketing, produkcja i rozwój produktowy.

Bardzo duży wpływ na działalność innowacyjną firmy wywierają również czynniki kreowane przez region, w którym ono funkcjonuje. Czynniki te 
to głównie: rynek pracy, zasoby wiedzy technicznej i informacji naukowej oraz gotowość instytucji do finansowania działalności obarczonej dużym stopniem ryzyka. Zatem sytuacja zewnętrzna przedsiębiorstwa będzie rozumiana jako zewnętrzny potencjał innowacyjny przedsiębiorstwa (Poznańska, 1998, s. 41).

W podobny sposób potencjał innowacyjny przedstawiany jest przez A. Żołnierskiego, który uważa, iż jest on determinowany przez wewnętrzny potencjał innowacyjny oraz dostęp do zewnętrznych źródeł innowacji.

Na wewnętrzny potencjał innowacyjny składa się (Żołnierski, 2005, s. 5-6):

1) kadra (jej wiedza i doświadczenie, umiejętności i kwalifikacje oraz sposób zarządzania dostępnymi zasobami, zarządzanie informacją),

2) badania i rozwój (wyodrębnione komórki $\mathrm{B}+\mathrm{R}$, prowadzone prace $\mathrm{B}+\mathrm{R}$, prace zlecane itp.),

3) technologia (komputery i technologia $\mathrm{ICT}^{1}$, maszyny i urządzenia, a także stopień nowoczesności maszyn i urządzeń).

Zewnętrzne źródła innowacji to przede wszystkim wyższe uczelnie i jednostki badawczo-rozwojowe, ale także firmy konkurencyjne czy odbiorcy i dostawcy.

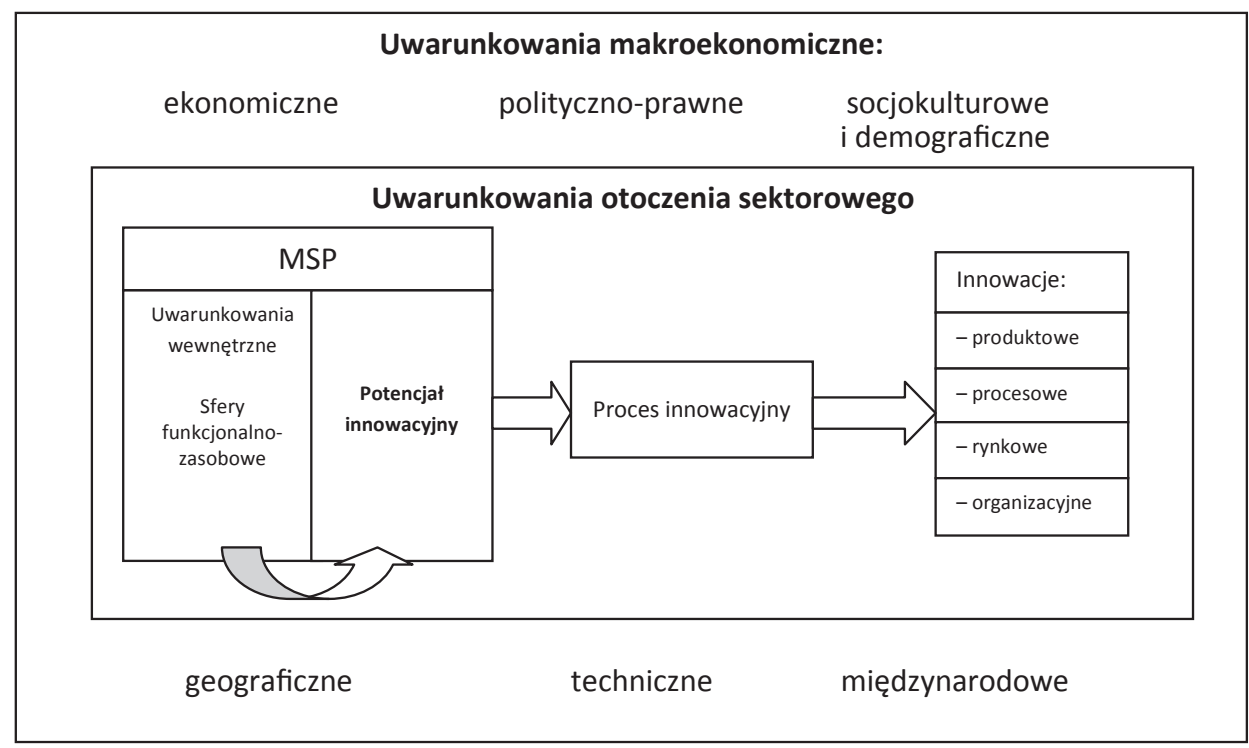

Rysunek 1. Potencjał innowacyjny i jego rola w procesie kreowania innowacji przez MSP według koncepcji M. Zastempowskiego

Źródło: Zastempowski, 2010, s. 275.

1 ICT - Information and communication technologies - technologie informacjno-telekomunikacjne. 
Zastempowski, skupiając się z kolei głównie na sektorze małych i średnich przedsiębiorstw, twierdzi, iż na tworzenie innowacji w tych przedsiębiorstwach wpływ mogą mieć zarówno uwarunkowania zewnętrzne związane z otoczeniem, w jakim one funkcjonują, jak i uwarunkowania wewnętrzne - związane z szeroko pojętymi zasobami, będącymi w posiadaniu przedsiębiorstwa (Zastempowski, 2010, s. 118-119). Zastempowski uważa, że ,potencjał innowacyjny to te zasoby, którymi małe i średnie przedsiębiorstwa powinny dysponować, aby skutecznie kreować i komercjalizować innowacje". Zasoby stanowią zatem podstawę budowanego przez przedsiębiorstwo potencjału innowacyjnego (Zastempowski, 2010, s. 153). Ten sposób ujęcia potencjału innowacyjnego prezentuje rysunek 1.

Analizując miejsce potencjału innowacyjnego w procesie kreowania innowacji, M. Zastempowski zaznacza, iż potencjał ten zależy od uwarunkowań zewnętrznych, dzieląc je na uwarunkowania dalsze, zwane makrootoczeniem, i bliższe, zwane otoczeniem sektorowym, oraz od uwarunkowań wewnętrznych tworzonych przez będące w dyspozycji MSP składniki sfer funkcjonalno-zasobowych. Dopiero odpowiednia ich kombinacja może tworzyć potencjał innowacyjny. Składać się ona może zarówno z zasobów niewidzialnych, jak i widzialnych, które odpowiednio wykorzystywane $\mathrm{w}$ procesie innowacyjnym pozwalają na wdrożenie innowacji (Zastempowski, 2010, s. 274-275).

\section{POTENCJAŁ INNOWACYJNY MSP MAKROREGIONU GRUDZIĄDZKIEGO - WYNIKI BADAŃ EMPIRYCZNYCH}

Badania empiryczne, których fragment wyników jest tu analizowany, przeprowadzono w ramach projektu badawczego pt. „Potencjał innowacyjny sektora MSP w województwie kujawsko-pomorskim”. Projekt realizowany był przez Wydział Nauk Ekonomicznych i Zarządzania w Katedrze Zarządzania Przedsiębiorstwem Uniwersytetu Mikołaja Kopernika w Toruniu od października do grudnia 2011 roku. Badanie przeprowadzono w mikro, małych i średnich przedsiębiorstwach całego regionu kujawsko-pomorskiego, jednakże niniejszy artykuł prezentuje wyniki badań, obejmujące przedsiębiorstwa makroregionu grudziądzkiego.

Jednym z celów szczegółowych projektu była próba identyfikacji kluczowych uwarunkowań zewnętrznych, wpływających na potencjał innowacyjny badanych firm, jak również identyfikacja kluczowych składników tego potencjału. 


\subsection{UWARUNKOWANIA ZEWNĘTRZNE BUDOWY POTENCJAŁU INNOWACYJNEGO BADANYCH PRZEDSIĘBIORSTW}

Analizę oddziaływania uwarunkowań zewnętrznych na budowę potencjału innowacyjnego małych i średnich przedsiębiorstw makroregionu grudziądzkiego przeprowadzono w ramach podziału otoczenia na makro- i mikrootoczenie (inaczej otoczenie sektorowe). Dokonano identyfikacji kilkudziesięciu zewnętrznych czynników kształtujących otoczenie przedsiębiorstwa ${ }^{2}$. Czynniki mogące wywierać zarówno stymulujący, jak i hamujący wpływ na budowanie potencjału innowacyjnego badanych przedsiębiorstw przypisano do obszaru makrootoczenia oraz otoczenia sektorowego.

Respondenci podczas badania ankietowego zostali poproszeni o ocenę, w jakim stopniu każdy z czynników wywiera stymulujący bądź hamujący wpływ na budowanie ich potencjału innowacyjnego. W ocenie kierowali się pięciostopniową skalą, którą prezentuje tabela 1 . W celu ustalenia ostatecznego kierunku siły wpływu każdego z czynników, obliczono średnią arytmetyczną ważoną i nazwano ją współczynnikiem oddziaływania S.

Tabela 1. Przyjęta skala siły oddziaływania czynników makrootoczenia i otoczenia sektorowego na budowanie potencjału innowacyjnego

\begin{tabular}{|c|c|}
\hline Skala & Oddziaływanie \\
\hline 5 & zdecydowanie pozytywny wpływ \\
\hline 4 & raczej pozytywny wpływ \\
\hline 3 & brak wpływu \\
\hline 2 & raczej negatywny wpływ \\
\hline 1 & zdecydowanie negatywny wpływ \\
\hline
\end{tabular}

Źródło: opracowanie własne.

Wyniki zaprezentowane na wykresie 1 świadczą o tym, iż uwarunkowania zewnętrzne wywierają nieznaczny pozytywny wpływ na budowę potencjału innowacyjnego badanych przedsiębiorstw. Najwyżej ocenione zostały uwarunkowania geograficzne, które uzyskały ocenę $S=3,38$. Na kolejnym miejscu znalazły się uwarunkowania technologiczne oraz socjokulturowe i demograficzne, uzyskując ocenę $S=3,24$. Uwarunkowania międzynarodowe oceniono na $S=3,21$, natomiast polityczno-prawne na $S=3,08$. Najniższą ocenę uzyskały uwarunkowania

2 Koncepcję oparto na badaniach empirycznych M. Zastempowskiego (2010, s. 167-180). 


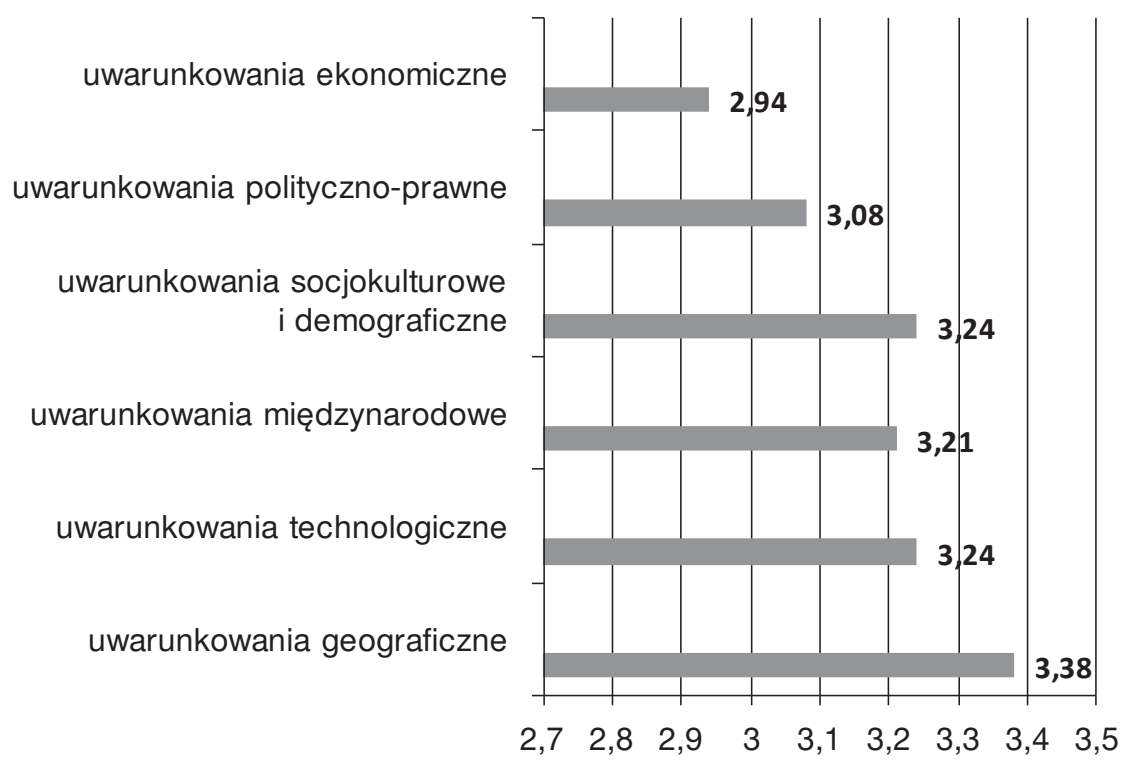

Wykres 1. Średni wpływ poszczególnych uwarunkowań makrootoczenia na budowanie potencjału innowacyjnego małych i średnich przedsiębiorstw makroregionu grudziądzkiego

Źródło: opracowanie własne na podstawie wyników badań w przedsiębiorstwach.

ekonomiczne $S=2,94$. Warto tu zauważyć, iż uwarunkowania te wywierają nieznacznie negatywny wpływ na budowanie potencjału innowacyjnego małych i średnich przedsiębiorstw makroregionu grudziądzkiego.

Analizując z kolei otoczenie sektorowe, należy zaznaczyć, iż wywiera ono dość pozytywny wpływ na budowanie potencjału innowacyjnego badanych przedsiębiorstw. Otoczenie sektorowe uzyskało średnią ocenę na poziomie $\mathrm{S}=3,49$.

\subsection{KLUCZOWE UWARUNKOWANIA ZEWNĘTRZNE BUDOWY POTENCJAŁU INNOWACYJNEGO BADANYCH PRZEDSIĘBIORSTW}

Aby skutecznie wdrażać innowacje i racjonalnie zarządzać potencjałem innowacyjnym w przedsiębiorstwie, należy skupić swoją uwagę przede wszystkim na tych uwarunkowaniach zewnętrznych, które okazują się kluczowe. Na uwarunkowania zewnętrzne bowiem składają się różnego rodzaju czynniki, których poziom istotności nie jest jednakowy. W przeprowadzonych badaniach 
dla identyfikacji kluczowych uwarunkowań zewnętrznych zastosowano metodę $\mathrm{ABC}^{3}$. Przyjmując regułę 20:80, można założyć, że w dalszej analizie należy skupić się na 20\% wszystkich analizowanych składników. Oczywiście nie chodzi tu o $20 \%$ dowolnie dobranych czynników, lecz o te najważniejsze. W celu ich wyodrębnienia zestawiono wszystkie 62 czynniki ze względu na współczynnik oddziaływania $\mathrm{S}$, począwszy od czynnika o najsilniejszym pozytywnym wpływie na budowę potencjału innowacyjnego badanych przedsiębiorstw. W tabeli 2 zaprezentowano ostateczne wyniki badań prezentujące już te kluczowe czynniki uwarunkowań zewnętrznych, mające wpływ na budowanie potencjału innowacyjnego respondentów4 .

Tabela 2. Czynniki uwarunkowań zewnętrznych wywierające największy wpływ na budowanie potencjału innowacyjnego badanych przedsiębiorstw

\begin{tabular}{|r|l|c|}
\hline Lp. & \multicolumn{1}{|c|}{ Czynniki } & S \\
\hline 1 & Poziom wsparcia informacyjnego & 3,77 \\
\hline 2 & Poziom wsparcia edukacyjnego i szkoleniowego & 3,77 \\
\hline 3 & Położenie geograficzne przedsiębiorstwa & 3,74 \\
\hline 4 & Poziom wsparcia finansowego & 3,74 \\
\hline 5 & Oferta szkoleniowa & 3,73 \\
\hline 6 & Stabilność kursu walutowego & 3,63 \\
\hline 7 & Stan infrastruktury & 3,63 \\
\hline 8 & Poziom wsparcia doradczego i badawczego & 3,63 \\
\hline 9 & Poziom wsparcia technologicznego & 3,63 \\
\hline 10 & Integracja z Unią Europejską & 3,59 \\
\hline 11 & Poziom wykształcenia ludności & 3,55 \\
\hline 12 & Procesy globalizacyjne & 3,55 \\
\hline 13 & Szybkość transferu techniki i technologii & 3,55 \\
\hline 14 & Poziom wsparcia organizacyjnego & 3,55 \\
\hline
\end{tabular}

Źródło: opracowanie własne na podstawie wyników badań w przedsiębiorstwach.

3 Metoda $\mathrm{ABC}$ opiera się na regule 20:80, która z kolei swoje źródło ma w koncepcji V. Pareto. Opierając się na tej koncepcji, można stwierdzić, iż pewną ogólną prawidłowością jest, że $20 \%$ elementów systemu determinuje $80 \%$ efektów tegoż systemu. Należy tu zaznaczyć, że nie chodzi tu o $20 \%$ dowolnie dobranych składników, lecz o te najważniejsze

$420 \%$ z 62 , to 12 czynników. W analizowanej sytuacji na 12 miejscu znalazły się 4 czynniki o tej samej ocenie $(S=3,55)$. Dlatego też do czynników o kluczowym znaczeniu zaliczono 14 czynników. 
Warto również przyjrzeć się tym wynikom przez pryzmat poszczególnych grup uwarunkowań. Okazuje się, że wśród najsilniej wpływających czynników znalazło się aż siedem uwarunkowań sektorowych (poziom wsparcia informacyjnego, edukacyjnego i szkoleniowego oraz finansowego, oferta szkoleniowa, poziom wsparcia doradczego i badawczego, a także poziom wsparcia technologicznego oraz organizacyjnego), po dwa czynniki geograficzne (położenie geograficzne przedsiębiorstwa oraz stan infrastruktury) i międzynarodowe (integracja z Unią Europejską i procesy globalizacyjne) oraz jeden czynnik z grupy socjokulturowych i demograficznych (poziom wykształcenia ludności), a także jeden technologiczny (szybkość transferu techniki i technologii). Wśród kluczowych czynników nie znalazł się ani jeden czynnik polityczno-prawny.

\subsection{ZASOBY I ICH WPŁYW NA BUDOWANIE POTENCJAŁU INNOWACYJNEGO BADANYCH PRZEDSIĘBIORSTW}

Analizując wpływ uwarunkowań wewnętrznych, czyli zasobów, jakimi dysponują małe i średnie przedsiębiorstwa na budowanie ich potencjału innowacyjnego, dokonano podziału ogółu zasobów na sfery funkcjonalno-zasobowe. Określono również poszczególne elementy w ramach analizowanych sfer, czyli tzw. składniki potencjału innowacyjnego ${ }^{5}$. Analizę przeprowadzono w ramach następujących sfer funkcjonalno-zasobowych: produkcji, zatrudnienia, logistyki, badawczo-rozwojowej, organizacji i zarządzania, zarządzania jakością, marketingu, zasobów niewidzialnych, finansów oraz informacji i komunikacji. W trakcie badania ankietowego respondenci zostali poproszeni o ocenę stopnia, w jakim składniki poszczególnych sfer ich przedsiębiorstwa wpływają na budowę ich potencjału innowacyjnego. Badane firmy w swej ocenie kierowały się pięciostopniową skalą: 5 - zdecydowanie pozytywny wpływ, 4 - raczej pozytywny wpływ, 3 - brak wpływu, 2 - raczej negatywny wpływ, 1 -zdecydowanie negatywny wpływ. Aby ustalić ostateczny kierunek siły wpływu każdego z poddanych ocenie składników, obliczono współczynnik oddziaływania S.

Uśrednione wyniki, uzyskane dla całej próby badanych przedsiębiorstw, zaprezentowane na wykresie 2 sugerują, iż w opinii respondentów ich przedsiębiorstwa dysponują zasobami, które przyczyniają się do kreowania i wdrażania innowacji.

5 Koncepcję takiego badania potencjału innowacyjnego przedsiębiorstw całkowicie oparto na badaniach prowadzonych przez M. Zastempowskiego (2010, s. 199-200). 


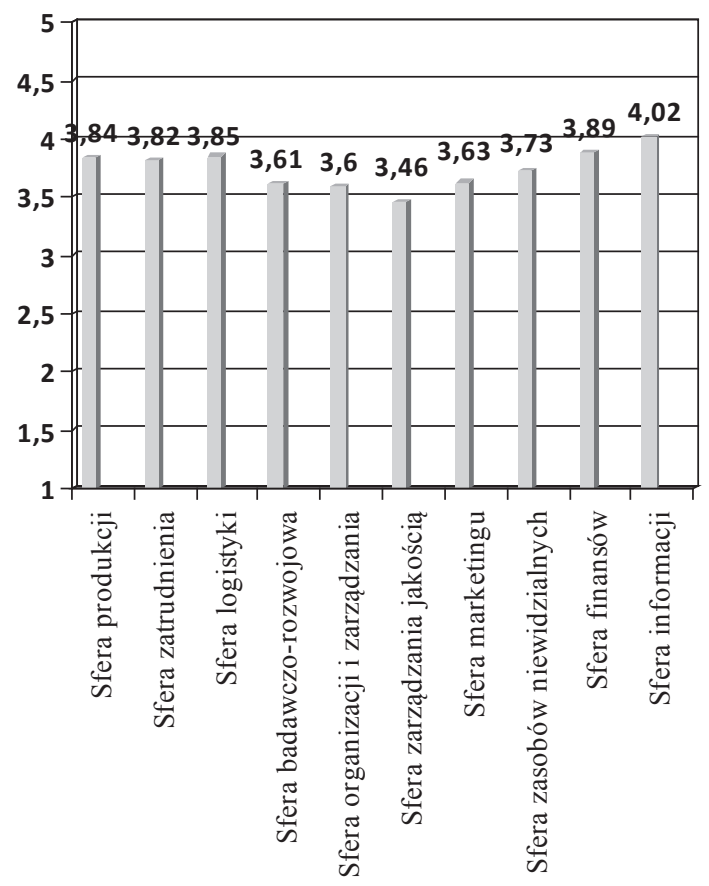

Wykres 2. Średni wpływ poszczególnych sfer funkcjonalno-zasobowych na budowanie potencjału innowacyjnego małych i średnich przedsiębiorstw makroregionu grudziądzkiego

Źródło: opracowanie własne na podstawie wyników badań w przedsiębiorstwach.

Najwyżej oceniono składniki sfery informacji. Zdaniem respondentów to one najsilniej wpływają na budowanie ich potencjału innowacyjnego $(S=4,02)$. Wysoko została oceniona sfera finansów $(S=3,89)$, a także sfera logistyki $(S=3,85)$. Na podobnym poziomie oceniono sferę produkcji $(S=3,84)$ oraz sferę zatrudnienia $(S=3,82)$. Na kolejnym miejscu znalazła się sfera zasobów niewidzialnych $(S=3,73)$, następnie sfera marketingu $(S=3,63)$, badawczo-rozwojowa $(S=3,61)$ oraz sfera organizacji i zarządzania $(S=3,6)$. Najniżej ocenione zostały składniki sfery zarządzania jakością $(\mathrm{S}=3,46)$.

\subsection{KLUCZOWE SKŁADNIKI POTENCJAŁU INNOWACYJNEGO BADANYCH PRZEDSIĘBIORSTW}

Podobnie jak w przypadku uwarunkowań zewnętrznych, dla identyfikacji kluczowych składników potencjału innowacyjnego również zastosowano regułę 20:80. Aby skutecznie go budować, należy skupić się na $20 \%$ wszystkich składników. 
Tabela 3 prezentuje wyniki badań wskazujące na owe kluczowe składniki potencjału innowacyjnego małych i średnich przedsiębiorstw makroregionu grudziądzkiego ${ }^{6}$.

Tabela 3. Kluczowe składniki potencjału innowacyjnego małych i średnich przedsiębiorstw makroregionu grudziądzkiego

\begin{tabular}{|c|c|c|}
\hline Lp. & Składniki & S \\
\hline 1 & Nowoczesność wyposażenia technicznego komórek B+R & 4,50 \\
\hline 2 & Potencjał finansowy przedsiębiorstwa & 4,46 \\
\hline 3 & $\begin{array}{l}\text { Wiedza, doświadczenie i zdolność menadżerskie kadr } \\
\text { kierowniczych }\end{array}$ & 4,31 \\
\hline 4 & Kreatywność pracowników & 4,30 \\
\hline 5 & Wydajność pracowników & 4,15 \\
\hline 6 & $\begin{array}{l}\text { Znajomość sytuacji na rynku zaopatrzenia i możliwość } \\
\text { przewidywania zmian }\end{array}$ & 4,15 \\
\hline 7 & $\begin{array}{l}\text { Wiedza, doświadczenie i zdolność menadżerskie kadr } \\
\text { zarządzających projektami }\end{array}$ & 4,15 \\
\hline 8 & Zdolność przedsiębiorstwa do uczenia się & 4,15 \\
\hline 9 & Doświadczenia i kontakty z przeszłości & 4,15 \\
\hline 10 & Dostęp do zewnętrznych źródeł finansowania & 4,15 \\
\hline 11 & Sprawność wewnętrznego systemu przepływu informacji & 4,15 \\
\hline 12 & $\begin{array}{l}\text { Znajomość potrzeb, preferencji i zachowań klientów i umiejętność } \\
\text { przewidywania zmian }\end{array}$ & 4,11 \\
\hline 13 & Wiedza, doświadczenie i zdolności kadry inżynierskiej & 4,07 \\
\hline 14 & Renoma i wizerunek przedsiębiorstwa & 4,07 \\
\hline 15 & Lojalność pracowników & 4,00 \\
\hline 16 & Nastawienie do innowacji kadr zarządzających & 4,00 \\
\hline 17 & Nastawienie do zmian kadr zarządzających & 4,00 \\
\hline 18 & Posiadane systemy wymiany informacji w przedsiębiorstwie & 4,00 \\
\hline
\end{tabular}

Źródło: opracowanie własne na podstawie wyników badań w przedsiębiorstwach.

Na składniki budujące potencjał innowacyjny badanych firm warto spojrzeć przez pryzmat poszczególnych sfer funkcjonalno-zasobowych. Do kluczowych składników tworzących potencjał innowacyjny respondenci zaliczyli aż 
pięć składników sfery zasobów niewidzialnych (zdolność przedsiębiorstwa do uczenia się, doświadczenia i kontakty z przeszłości, renoma i wizerunek przedsiębiorstwa, nastawienie do innowacji kadr zarządzających oraz nastawienie do zmian kadr zarządzających), trzy składniki sfery zatrudnienia (kreatywność pracowników, ich wydajność oraz lojalność), po dwa składniki sfery organizacji i zarządzania (wiedza, doświadczenie i zdolności menadżerskie kadr kierowniczych oraz kadr zarządzających projektami), sfery finansów (potencjał finansowy przedsiębiorstwa oraz dostęp do zewnętrznych źródeł finansowania) oraz sfery informacji (sprawność wewnętrznego przepływu informacji i posiadane systemy wymiany informacji w przedsiębiorstwie, a także jeden składnik sfery produkcji (wiedza, doświadczenie i zdolności kadry inżynierskiej), sfery logistyki (znajomość sytuacji na rynku zaopatrzenia i możliwość przewidzenia zmian), sfery badawczo-rozwojowej (nowoczesność wyposażenia technicznego komórek $\mathrm{B}+\mathrm{R}$ ) oraz sfery marketingu (znajomość potrzeb, preferencji i zachowań klientów i umiejętność przewidywania zmian). Co ważne, żaden ze składników sfery zarządzania jakością nie okazał się kluczowy w budowie potencjału innowacyjnego badanych przedsiębiorstw. Potwierdzeniem tego jest również fakt, iż cała sfera zarządzania jakością uzyskała najniższą ocenę w opinii respondentów, zatem ma ona dla nich najmniejsze znaczenie przy tworzeniu ich potencjału innowacyjnego.

Na pierwszym miejscu wśród kluczowych składników potencjału innowacyjnego badanych MSP znalazła się nowoczesność wyposażenia technicznego komórek B+R. Respondenci podkreślają zatem bardzo duże znaczenie działalności badawczo-rozwojowej w swym przedsiębiorstwie, jednakże tylko jeden ze składników tej sfery został zaliczony do tych kluczowych. Na kolejnym miejscu respondenci wskazali potencjał finansowy przedsiębiorstwa, bez którego oczywiście nie można by prowadzić działalności innowacyjnej, gdyż wielokrotnie wymaga ona sporych nakładów kapitałowych. Tym samym podkreślają znaczenie dostępu do zewnętrznych źródeł finansowania. Do kluczowych składników zaliczono również te związane z zatrudnioną kadrą - zarówno tą kierowniczą, jak i z szeregowymi pracownikami. Respondenci podkreślają znaczenie składnika, jakim jest wiedza, doświadczenie i zdolności menadżerskie kadr kierowniczych, nastawienie do innowacji oraz do zmian kadr zarządzających, jak również sama kreatywność, wydajność oraz lojalność pracowników. Wśród kluczowych składników znalazły się takie, jak znajomość sytuacji na rynku zaopatrzenia i możliwość przewidywania zmian oraz znajomość potrzeb, preferencji i zachowań klientów i umiejętność przewidywania zmian. Badane firmy zaznaczają zatem, jak istotne jest $\mathrm{w}$ procesie tworzenia potencjału innowacyjnego umiejętne monitorowanie otoczenia. Wiedza, doświadczenie i zdolność menadżerskie kadr zarządzających projektami, a także wiedza, doświadczenie i zdolności kadry 
inżynierskiej to kolejne kluczowe składniki potencjału innowacyjnego małych i średnich przedsiębiorstw makroregionu grudziądzkiego. Podkreśla się tu ponownie bardzo duże znaczenie szeroko pojętej wiedzy w tworzeniu potencjału innowacyjnego. Zdolność przedsiębiorstwa do uczenia się, jego renoma i wizerunek, a także doświadczenia i kontakty z przeszłości to kolejne trzy kluczowe składniki potencjału innowacyjnego badanych firm. Sprawność wewnętrznego systemu przepływu informacji oraz systemy wymiany informacji w przedsiębiorstwie to dwa kluczowe składniki tworzące potencjał innowacyjny badanych MSP, należące do sfery informacji - uznanej przez respondentów za najważniejszą.

\section{PODSUMOWANIE}

Zaprezentowane powyżej wyniki badań empirycznych, dotyczących potencjału innowacyjnego małych i średnich przedsiębiorstw makroregionu grudziądzkiego, pozwalają na sformułowanie kilku wniosków.

Po pierwsze, analizując wpływ zewnętrznych uwarunkowań na budowanie potencjału innowacyjnego, respondenci wskazują na największe znaczenie uwarunkowań geograficznych spośród wszystkich grup uwarunkowań makroekonomicznych.

Po drugie, aż siedem czynników z otoczenia sektorowego znajduje się w grupie kluczowych uwarunkowań zewnętrznych, wywierających wpływ na budowanie potencjału innowacyjnego badanych przedsiębiorstw.

Po trzecie, sferą funkcjonalno-zasobową wywierającą najsilniejszy wpływ na budowanie potencjału innowacyjnego badanych MSP jest sfera informacji.

Po czwarte, patrząc na kluczowe składniki potencjału innowacyjnego badanych firm przez pryzmat podziału ogółu zasobów na materialne i niematerialne, zauważyć można ogromną rolę tych drugich. To one w zdecydowanej większości tworzą potencjał innowacyjny małych i średnich przedsiębiorstw makroregionu grudziądzkiego.

\section{LITERATURA}

Poznańska K. (1998), Uwarunkowania innowacji $w$ matych $i$ średnich przedsiębiorstwach, Dom Wydawniczy ABC, Warszawa.

Zastempowski M. (2010), Uwarunkowania budowy potencjału innowacyjnego polskich matych i średnich przedsiębiorstw, Wydawnictwo Naukowe UMK, Torun.

Żołnierski A. (2005), Potencjat innowacyjny polskich małych i średniej wielkości przedsiębiorstw, Polska Agencja Rozwoju Przedsiębiorczości, Warszawa. 


\section{THE INNOVATIVE POTENTIAL OF SMALL AND MEDIUM ENTERPRISES OF GRUDZIĄDZ MACROREGION}

Abstract: This article presents a fragment of results of empirical research on innovational potential of small and medium enterprizes in the Kuyavian-Pomeranian Voivodeship. One of the aims of this research was the identification of external key conditions influencing the innoventional potential of small and medium enterprises, as well as the identification of key elements of this potential. The study illustrates the outcome of research on enterprizes of Grudziądz macroregion.

K e y w ords: innovative potential, small and medium-sized enterprises. 
